\title{
The Impact of Capital Structure on Islamic Banks Performance: Evidence from Pakistan
}

\author{
ATTA ULLAH \\ MBA Student, Abdul Wali Khan University, Mardan \\ MUHAMMAD ILYAS \\ Lecturer, Abdul Wali Khan University, Mardan \\ Milyas85@awkum.edu.pk \\ IHTESHAM KHAN \\ PhD Scholar, Islamia College University Peshawar \\ ihtishamkhan@awkum.edu.pk \\ MUHAMMAD TAHIR KHAN \\ Lecturer, Abdul Wali Khan University, Mardan \\ mtahir@awkum.edu.pk
}

\begin{abstract}
This study investigate the impact of capital structure on the Islamic banks performance during 2008-2013. Selected a sample of 5 Islamic banks on the basis of availability of data. From the findings of the study demonstrate that the impact of capital structure and size is positive and significant on Islamic banks performance. However, Assets Growth is negatively and statistically non-significantly associated with banks performance.
\end{abstract}

Keywords: Return on Equity, Capital Structure, Size and assets Growth.

\section{Introduction}

Capital structure is the combination of debt and equity that a firm uses to finance its business (Damodaran, 2001). Miller and Modigliani (1958) recommended that, under perfect capital market, there is no change in debt and equity financing as regard to the value of the firm. Hence, financing choice adds no value. Evidence recommended that this does not hold in reality. Although, capital structure is one of the essential financial decisions for any corporate firm. Furthermore, the impact of capital structure choice will help the firm's ability to deal with its competing situation. Moreover, capital structure of a corporate organizations is a combination of equity and debt that a firm uses to improve its business operation. Therefore, specific strategy of a firm should deal with the suitable combination of equity and debt to finance its assets. Capital structure decisions, not only involve investment decisions for a business organization. It includes a massive amount of funds and has long term implications for a corporations. However, Modigliani and Miller (1958) examined and discussed that capital structure is not relevant in an ideal situation, a capital market with, investor's homogeneous expectations no transaction costs associated with debt and no taxes. 
In 1963, Miller and Modigliani proposed the presence of corporate taxes a firm apply debt as much as possible in order to increase firm value by increasing the tax shield benefits. The capital structure decision with the firm performance was suggested in several numbers of theories include the tradeoff theory, pecking order theory and agency cost theory. Pecking order theory suggest that firms will mainly rely on inside funds and if the funds are not enough to meet organizational goals then they will go for debt financing and at the end issue equity to cover any remaining requirements (Majluf \& Myers, 1984). Gleason, Mathur and Lynette (2000) recommend that use of various levels of equity amount and debt amount in the firm's capital structure is one of the firm exact strategies utilized by executives to increase firm's profitability. Therefore, organizations try to develop its competitive edge in the marketplace through a combination of equity and debt (Myer, 2001). James and Headlock (2002) concluded that corporate firms prefer debt financing because they assume a higher return. Moreover, leverage improve firm performance (Champion, 1999).

A number of studies was elucidated to analyze the subject to examine the impact of capital structure on organization profitability. Some studies prove that there is positive impact of capital structure on organization performance. Roden and Lewellen (1995) revealed significantly positive association between capital structure and organization performance. Moreover, same results demonstrate by (Berger and Patti (2006); Chien and Cheng (2010); Jang and Park (2013) Psillaki and Margaritis (2007). However, some of the studies conclude inverse relationship between capital structure and firm financial performance. (Chakraborty, 2010; Ebaid, 2009; Gleason, 2000; Hayajneh \& Soumadi, 2012; Paudyal \& Guney, 2008). Mujahid and Malik (2014) banks play a primary role in the economic performance through their financial intermediation function, monetary policy mechanism and in providing economic stability.

Globally various research work conducted to investigate the impact of capital structure on Islamic banks performance in different region with a different time periods. However, limited number of studies done due to the fact that data of Islamic banks have been unavailable due to their recent growth (Merchant, 2012). In the context of Pakistan small research work is investigated. Therefore, this study pursued to fill the research gap and to investigate the Impact of capital structure on the financial performance of Islamic banks in Pakistan.

\section{Literature Review}

Miller and Modigliani (1958) the widely known theory of "capital structure irrelevant proposition" presented that leverage does not influence the organization value under perfect market situation. Miller and Modigliani indicated that in ideal world there is no transaction cost associated with funds raising, no tax effect and all information provided by organization is reliable then capital structure does not influence an organization value. Hamaada (1969) and Satiglitz (1974) support the theory. However, this theory was based on expectations which in contradiction with real world. Where organizations generally utilize an optimum level of debt (Campello, 2006). Miller and Modigliani Irrelevancy theory of has been criticized on the base of the Irrelevance theory undertakes perfect market situations and balanced economic behavior according to 
Chaganti et.al. (1995) theory restricted and only applicable for small business firms. After their initiative demonstration present that capital structure is irrelevant to organization value, In 1963 Miller and Modigliani reviewed their theory of capital structure by adding corporate tax assistances as an element of the capital structure. In this new aspect, important component of taxation is the recognition of interest as tax deductible expenditure. To support this dispute, Miller and Modigliani describe that a firm increase debt financing will partially benefit from low tax payment called tax shield. M\&M indicate that a firm increase its debt financing can get more profit and increase firm value because increase in debt finance also increase the tax shield benefits for the firms.

M\&M theory support for other theories that are proposed by other scholars with the attention of other market limitations. Majluf and Myers (1984) elaborated this theory they says that a firm will primarily depend on internal source of financing, no chance of information asymmetry firm will produce high returns are expected to utilize less debt. In addition, Mackling and Jensen (1976) has advanced agency theory where they conclude that agency costs are those costs that are attached the agent, monitoring expenses by the principal and an outstanding loss. The presence of agency problem arises owed to the clashes among business executives and shareholders or between debt holders and shareholders, to reduce the agency cost use of debt more reliable tool for it. Leverage can force executives to produce and pay out cash, just because interest expenses are mandatory. Interest expense will decrease the amount of residual cash flows. Thus, debt is observed as a sensible method to decrease the agency costs. Newman and Kinsman (1998) recommended that advanced levels of debt are associated with lower firm performance based on the association amongst three analyzes of debt level. The finding reveals that short-term debt was negatively associated with earnings but positively associated with long-term debt. Though generally results determine an opposite association between debt and firm performance. Chhibber and Majumdar (1997) support this result because this research study indicate a negative association, which is not in consensus with agency theory as generally recognized. Furthermore, size found to be positively associated with firm performance.

Gleason et.al. (2000) investigate the association between performance and leverage by ROA. The findings show that debt has a negative and significant impact on performance. Research by Lara and Mesquita (2003) indicate that long-term debt has negative sign while a short-term debt has a positive sign. It also recommended that shortterm debt is exercise among the most effective firms; short-term debt easily rises from financial organizations. Sipahioglu and Philips (2004) investigate the association between capital structure and firm performance and find insignificance association between financial performance and firm debt level. This result is inverse with earlier research was done by Miller and Modigliani (1963) in which they illustrates that debt does not directed to higher returns and performance as indicated in information asymmetric theory, but could recently devote to low performance as indicated in agency theory. This investigation recommended that the organizations that have a lower level of debt perform better than firms have a high level of debt. Abor (2005) investigate the 22 firms listed in the Ghana results indicates that short-term debt has positive and statistically significant in association with return on equity. Short term debt is less costly than long term debt as 
results show positive and significant but increase in long term debt decrease organization profitability. While for total debt the result shows positive association, increase in debt level will lead increase in profitability. The result also shows positive association for both sales growth and firm size. These findings support the James and Hadlock (2002) where more debt use by profitable firms. However, Carpentier (2006) findings shows no significance correlation between change in debt and change in value. Only size and profitability found significant which are positively associated with change in value in each variable. While assets growth is not significant to change in value. Abor (2007) initiate a negative association between all the dimensions of the capital structure and organization performance in the study of Ghana.

In study sample of South African organizations found short term debt statistically significant and have a positive impact with return on assets it illustrate that short term debt is implied to be comparatively less costly, increasing short run funds is due to low interest rate and in return get high profit. The result shows negative association for long term and total debt. Because long term debt charges higher, cost and gets low returns. These findings support the Abor (2005) study. Furthermore, study found positive significant for size and a negative result for sales growth on return on assets (ROA) (Abor, 2007). Raheman (2007) conducted a study of 94 corporate firms listed in Islamabad Stock Exchange (ISE) Regression and Pearson's correlation analysis find the relationship of capital structure with firms profitability, after evaluating financial statements of the firms it is proved that capital structure has impact firm profitability. Malekian, Lotfollahpour \& Bagheri (2012) analyze the 400 firms from 12 sectors listed in Tehran Stock Exchange (TSE); the study indicates that positive association among capital structure and firm performance. Priya and Nirajini (2013) used data from trading firms listed in Sri Lanka Stock Exchange (SLSE) from the year 2006 to 2010 and used multiple regression and correlation analysis and the result indicates a significant association between capital structure and firm performance. Impact of capital structure on financial institutions first analyzed by Berger (2006) results show a positive association between capital ratio and earnings ratio of the bank. Campello (2007); Psillaki and Margaritis (2007); found that if a firm increased debt level and firm's assets are more tangible than the firm's performance will also increase as compared to the market rivals. Tang, Jang and Chen (2008) investigated that firm value increases if a firm used only debt for financing activities.

According to Liu and Cheng (2010) if the leverage of a firm is balanced the capital structure will be positively related to firm performance. Morogie and Erah (2010); and Champion (2010); also support Margariti and Psillaki (2007); by finding that capital structure positively related to firm performance. Chowdhury (2010) study investigate 77 listed firms on Chittagong and Dhaka Stock Exchange, results provide a positive and strong correlation among capital structure and organization performance. Firm performance and capital structure is positively related to each other. Shoaib (2011). Badriyah and Ismail (2011) examined the Malaysian listed banks the results indicate a positive association between leverage and profitability, assets and firm growth also found positive association with each other. Capital structure positively related to the firm profitability means if capital structure increases the profitability of a firm will also 
increase, Aman (2011). Jang and Park (2013) found a positive association among capital structure and firm profitability after the analysis of 308 firm data from 1995-2008 efficient use of debt reduce cash flow and increase firm performance. Song and Huang (2006) study investigate Chinese firms results indicates a negative association between capital structure and firm performance. Leverage is negatively relation to performance. Ghosh (2007). Hameed et.al (2007) investigates Oman firms study found a firm performance is negatively and significantly related to capital structure decision. Madan (2007) examine the importance of capital structure decision with the whole performance of corporate firms. Study found that a few firms positively affected by leverage and the rest of all corporations effect negatively. Tian and Zeitun (2007) analyze the firm's capital structure through return on assets and return on equity results indicates significant and positive impact on firm performance the results support the previous work done by Myers (1997) that firm STD to TA have a high growth and performance. The size of firm found a positive effect on performance large size firm has low level of bankruptcy costs. Ebaid (2009) results indicates total debt and short term debt negatively effect on organization financial performance measure through return on assets. In addition, measure through return on equity (ROE) capital structure has no effect on banks performance. The result for return on equity (ROE) is same with Mahmoodi and Saeedi (2011) but not for the return on assets (ROA) who found it is associated with short term debt, long term debt and total debt.

Thornton and Molyneux (1992) first to discover the determinants of banks profitability, they study sample consist of 18 Countries for the period of (1986-1989). The study found a positive and significant relation between the return on equity and interest rate, government ownership and concentration ratio in each country. Mendes and Abreu (2002) examine the determinants of banks interest and profitability for European countries. The study found that banks the lower bankruptcy cost because of their size and providing different type of product and services that translate better performance and profitability. While a negative significant in all regressions models. The study also find inflation rate and unemployment is relevant to the bank's profitability. Bergr (2006) examine the financial institutions found a positive association among earning of banks and capital structure decision. In 1997, DeYoung test the banks efficiency and indicate that there is a positive association among efficiency, quality of loan and bank capital. Banks are highly levered as compared to non-financial institutions; banks are influenced by debt in the same way as other non-financial institutions, (Flannery, 1994).

The major function of a bank is to make loans; financial institution is highly levered than others. Muller (2008). Banks functional approach to capital structure proposed by Rajan and Diamond (2000) suggest that banks capital structure determinants should by be modeling the important function of banks performance. Ismail and Pratomo (2006) investigate the agency cost theory on Malaysian banks and found that lower equity ratio leads to high-profit efficiency Shoaib and Siddiqui (2011) agreed with Ismail (2006) who done their study on Pakistani banks As applies case in Indonesian Banks. The study aims to test the profitability indicators and performance of Islamic bank in Indonesia, where the survey found that investment funds that do not include benefits have no effect on the profitability of banks. (Izhar \& Asutaya, 2007). Saeed (2013) investigate 
impact of capital structure on the performance banks, which took five years from 2007 to 2011 to be examine, performance measure through return on equity, return on assets and earnings per share. While the elements of the capital structure include long term debt, short term debt and total debt to capital ratio. Results show positive association between elements of capital structure and performance of banks. Bashir (2000) investigate the elements of Islamic bank's financial performance across 8 different countries for the time period of (1993-1998). Many of the capital structure determinants were used to predict the Islamic banks efficiency and profitability. The study took the Taxation, Macroeconomics environment and Financial Markets situation as control variables. The study results show that loans to total assets, leverage lead to a higher level of profitability. Hassan and Bashir (2004) results show that the Capital assets ratio is performing better in Islamic banks as compare to conventional banks that show well capitalization of Islamic banks. These results further support by (Iqbal, $2001 \& 2004$ ) the study also conclude that Depositors of conventional banks are safer than Islamic banks depositors because the rate of return is fixed in conventional banks as compare to Islamic banks return where it is not fixed that why depositors demand more rate of return. More favorable ratio as per international standard in Islamic banks is Profit ratio. The study also reports that international banks are more profitable as compare to national Islamic banks. Association of taxation with banks profitability found negative and macroeconomics and stock market improvement have a positive effect on Islamic banks profitability.

In order to accomplish the goals of the financing of any company, it must be a funding process suited in harmony with company goals, through the identification of the optimum mix of financing, the capital structure which will lead to the extreme possible value, valuable source of funding include a mix of debt and equity, will finance projects through debt commitment and responsibility which results in an effect on cash flows, regardless of the success of the project, as earlier research study done by Khalid and Zaher (2014). Test the consequence of capital structure on the performance of Jordanian Islamic Banks in which they use several financial ratios as independent variables (Total Assets Ratio, Ratio of Financing, Liquidity ratio, Equity ratio and bank concentration ratio) while the performance took as dependent variable that is measured by Scale Tobin Q (market value of bank), the study found a positive effect for each ratio only concentration ratio has a negative effect while liquidity ratio has no effect on Performance. A firm's performance effect by debt maturity and capital structure choice debt maturity effects a firm's investment options. In addition, the tax rate is anticipated to have an impact on organization performance. Therefore, examine the impact of capital structure elements on a firm's performance will provide indication of the effect of capital structure on organization performance (Zeitun, 2007).

\subsection{Hypothesis of the Study}

$\boldsymbol{H}_{1}$ : There is no Impact of capital structure on the performance of Islamic banks in Pakistan. 


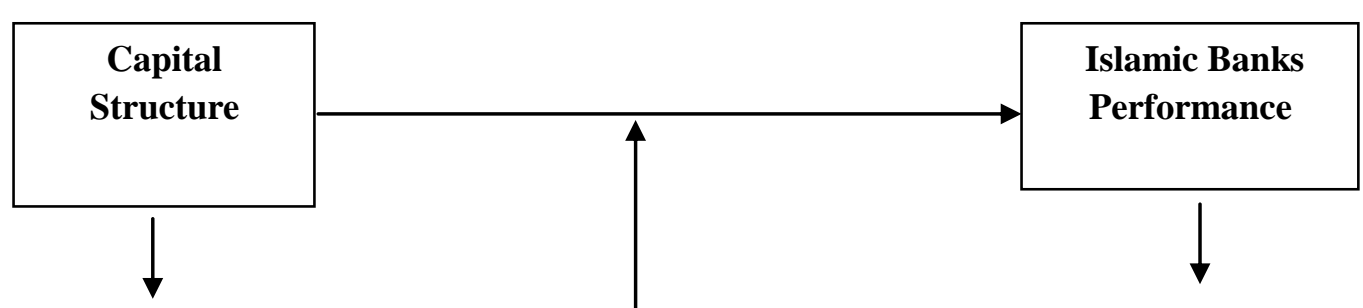

Debt to Assets

Return on Equity

Assets Growth \& Size

Figure 1: Conceptual Framework of the Study

\section{Research Methodology}

The study populations consist of all Islamic banks in Pakistan but some banks operate with both Islamic and conventional banking practices. Therefore, only five pure and classified Islamic banks were selected for investigation. Nature of data is secondary. And collected from the State bank of Pakistan annually Publication and Annual reports of the particular Islamic banks.

\subsection{Variables of the study}

\subsubsection{Dependent variable}

To measure the performance used return on equity as proxy. It is calculated through net income divided by shareholders equity. Return on equity show how a firm use shareholders equity to generate profit.

\section{i. Independent Variable}

a. Debt to Total Assets

Ratio of debt to total assets and debt is supposed to have a positive impact on the profitability of the banks (Khalid \& Zaheer, 2014).

b. SIZE

Is the control variable and represent the bank size, to measure the size study take the natural logarithm of the size of the Bank's assets, larger-sized banks mostly take advantage of their large size to acquire the cost savings which increase the profit of those banks (Goaied \& Naceur, 2001).

\section{c. Assets Growth}

Growth assets are intended to grow bank investment. Such as shares, different investments and property, and tend carry higher level of risk, however have the potential to deliver higher returns over longer investment time frames. 
Table 1: Abbreviation and Measurement of Variables

\begin{tabular}{|lll|}
\hline Variables & Abbreviation & Measurement \\
\hline Return on Equity & ROE & Net Income / Shareholders' equity \\
Debt to Total Assets & DTA & $\begin{array}{l}\text { Total Debt / Total Assets } \\
\text { Assets current Year - assets previous } \\
\text { Assets Growth }\end{array}$ \\
AG & \\
Firm Size & SIZE & Ln ( Total Assets ) \\
\hline
\end{tabular}

Research Model

Multiple regression model is used:

$\mathrm{ROE}_{\mathrm{it}}=\beta_{0}+\beta_{1} \mathrm{DTA}_{\mathrm{it}}+\beta_{2} \mathrm{SIZE}_{\mathrm{it}}+\beta_{3} \mathrm{AG}+\mu_{\mathrm{it}}$

Where:

$\mathrm{ROE}_{\mathrm{it}}$ is return on equity of bank $i$ at time $t$.

DTA $_{\text {it }}$ is capital structure ratio of bank $i$ at time $t$.

SIZE $_{i t}$ is size of bank $i$ at time $t$.

$\mathrm{AG}_{\mathrm{it}}$ is asset growth of bank $i$ at time $t$.

$\mu_{\mathrm{it}}$ is error term.

\section{Results and Discussion}

Table 4.1: Regression Analysis

\begin{tabular}{|l|l|l|l|l|}
\hline Variable & Coefficient & Std. Error & t-Statistic & Prob. \\
\hline Constant & -2.349 & 0.317 & -7.417 & 0.000 \\
\hline DTA & 0.132 & 0.124 & 1.067 & 0.001 \\
\hline SIZE & 0.091 & 0.014 & 6.375 & 0.000 \\
\hline AG & -0.007 & 0.088 & -0.078 & 0.938 \\
\hline
\end{tabular}

Adj-R-Square 68.3\%

Coefficient of DTA is positive and statistically significant at level of $1 \%$. Therefore, the Null Hypothesis has been rejected. Moreover, t-value is less than 2 that show a weak impact of DTA on ROE which means that each $0.1 \%$ increase in Debt will increase $13.2 \%$ of profit for Islamic banks. The results support the study of (Abor (2005); Aman (2011); Jang and Park (2013); Khalid and Zaheer (2014); Myers (1997); Priya and Nirajini (2013); Zeitun and Tian (2007). However, the results are different from the stud studies of (Ebaid (2009) and Sipahioglu and Philips (2004). The results further indicate 
that the coefficient of size is positive and statistically significant at the level of $1 \%$, that show a strong impact of size on Islamic banks performance. The result of size variable support the study results of (Abor (2005); Gleason et.al. (2000); Khalid and Zaheer (2014); Raheman et.al, (2007); Saeed et.al. (2013). Assets Growth find negative and statistically insignificant at a level of $1 \%$, results of AG support previous studies conducted by of (Abor, 2007); Haseeb and Arif (2013); Saeed et.al. (2013). R R implies that $68.3 \%$ of the variation in performance (ROE) can be explained by the model variables.

\section{Conclusion}

In this research study researchers investigate the impact of capital structure on Islamic banks performance during 2008-2014. Used multiple regression models for analysis. From the results of the study found that Debt to Assets and size have positive and significance impact on Islamic banks performance, however, Assets Growth is negatively and insignificantly related with Islamic banks performance.

\section{References}

Abbadi, M, S., \& Abu-Rub, N. (2012). The effect of capital structure on the performance of Palestinian financial institutions. British journal of economics, finance and management sciences vol. 3 (2), 92-101.

Modigliani, F., \& Miller, M. H. (1958). The Cost of Capital, Corporation Finance and the Theory of Investment. The American Economic Review, Vol.48, No. 3, 261-297.

Al-Farisi, A., \& Hendrawan, R. (n.d.). Effect of capital structure on banks performance: Aprofit Efficiency approach islamic and conventional banks case in indonashia.

Ismail, A. G., \& Pratomo, W. A. (2006). Islamic bank performance and capital Structure. MPRA Paper no. 6012, posted 29. 2007 13:38 UTC.

Izhar, H., \& Asutay, M. (2007). Estimating the Profitability of Islamic Banking: Evidence from Bank Muamalat Indonesia. International Association for Islamic Economics Review of Islamic Economics, vol.11, No.2, 17-29.

Mujahid, M., \& Sameen, S. N. (2014). Impact of capital structure on banking performance. Research Journal of Finance and Accounting ISSN 2222-1697 Vol.5,No.19,2014, 99-104.

Damodaran, A. (2001). Corporate Finance: Theory and Practice, 2nd Edition.

Rajha, K. S., \& Fattah, Z. A. (2014). The Effect Of capital structure on the performance of islamic banks. Interdisciplinary Journal of contemprary research in bussiness Vol.5 No.9, 144-161.

Saeed, M. M. (2013). Impact of Capital structure on banking performance (a case study of pakistan). Interdisciplinary Journal of contemprary research in bussiness Vol.4, No.10, 393-403.

Sidduqui, M. A., \& Shoaib, A. (2011). Measuring performance through capital structure: Evidence from banking sector of pakistan. African journal of Business Management Vol.5(5),, 1871-1879. Retrieved from http://www.academicjournals.org/AJBM

Ansari, A., Rahman, K., (2011). Comparative financial Performance of existing Islamic Banks And contemporary conventional Banks in Pakistan. International 
Conference of Economics, Business and Management, Vol.22 IACSIT Press, Singapore

Nikoo, S. F. (2015). Impact of Capital Structure on Banking Performance: Evidence from Tehran Stock Exchange. International Research Journal of Applied and Basic Sciences, Vol, 9 (7), 1148-1152.

Umar, M., Tanveer, Z., \& Aslam, S. (2012). Impact of Capital Structure on Frms' Financial Performance. Research Journal of Finance and Accounting, Vol 3, , 2222-2847.

Javed, T., \& Younas, W. (2014). Impact of capital structure on Firm performance: Evidience from Pakistani Firms. International Journal of Academic Research in Economics and Management Sciences, Vol. 3, 2226-3624.

Mujahid, M., \& Akhtar, K. (2014). Impact of Capital Structure on Firms Financial performance and Shareholders Wealth: Textile Sector of Pakistan. International Journal of Learning \& Development, Vol.4, 2164-4063.

Ahmad, T. (2014). Imapct of Capital Structure on Profitability: An empirical Analysis of Cement Sector of Pakistan. Research Journal of Finance and Accounting, Vol.5(17).

Al-Tanani, K. (2013). The Relationship between Capital Strucure and Firm Performance : evidene from Jordan. Journal of Finance and Accounting, 41-45. Retrieved from http;//www.sciencepublishinggroup.com/j/jfa

Appiadjei, E. A. (2014). Capital Structure and Firm Performance; Evidence from Ghana Stock Exchange. Reseach Journal of Finance and Accounting, Vol.5.

Ba-Abbad, K., \& Ahmad-Zaluki, N. A. (2012). The Determinants of Capital Structure of Qatari Listed Companies. International Journal of Accademic Research in Accounting, Finance and Management Sciences, Vol.2(2), 93-108.

Berger, A. N., \& Di Patti, E. B. (2006). Capital Structure and Firm Performance: A New Approach to Testing Agency Theory and an Application to the Banking Industry. Journal of Banking \& Finance, Vol.30(4), 1065-1102.

Carpentier, C. (2006). The Valuation Effects of Long-term Changes i Capital Structure . International Journal of Managerial Finance, Vol.2(1), 4-18. doi:10.1108/17439130646144

Chhibber, P., \& Majumdar, S. (1997). Capital Structure and Performance : Evidence from a Transition Economy on an Aspect of Corporate Governance. 287-305. doi:10.1023/A:1018355127454

Chowdhury, P. S., \& Chowdhury, A. (2010, Otober). Impact of Capital Structure on firms value: Evidence from Bangladesh. Business and Economics Horizons, Vol.3(Issue 3), 111-122.

Dada, F. B., Oino, I., \& Ukaegbu, B. (2014). The Impact of Ownership Structure on Capital Structure and Firms Performance in Nigeria. Research Journal of Finance and Accounting, Vol.5, No. 15, 82-89.

Dube, H. (2013). The Impact of Debt Financing on Productivity of Small and Medium Scale Enterprises(SME's): A case Study of SME's in Masvingo Urban. International Journal of Economics, Business and Finane, Vol. 1, 371-381. 
Gleason, K., Mathur, L. K., \& Mathur, I. (2000). The Interrelationship between Culture,Capital Structure, and Performance:Evidence from European Retailers. Journal of Business Research, 185-191. doi:10.1016/S0148-2963(99)00031-4

Emamgholipur, M., Lotfollahpour, V., \& Bagheri, M. M. (2012). The Relationship between Capital Structure and Firm Performance Evaluation Measures: Evidence from Tehran Stock Exhange. International Journal of Business and Commerce, Vol.1, 166-181. Retrieved from www.ijbcnet.com

Foo, V., Abdul Jamal, A. A., Abdul Karim, M. R., \& Baharul Ulums, Z. K. (2015). Capital Structure and Corporate Performance: Panel Evidence from Oil and Gas Companies in Malaysia. International Journal of Business and Economic Research, Vol.6, 371-379.

Handriks, G. (2011). The Determinants for the Capital Structure choice of United States firms compared to United Kingdom firms. Journal of Financial Economics, 1001-1022.

Harris, M., \& Raviv, A. (1991). The Theory of Capital Strucure. The Journal of Finance by American Finance Assosiation, Vol.46, 297-355.

Javed, B., \& Akhtar, S. (2012). Interrealationship between Capital Structure and Financial performance, Firm Size and Growth: Comarison of industrial sector in KSE. Europen Journal of Business and Management, Vol.4(No.15), 148-157.

Javed, T., \& Younas, W. (2014). Impact of capital structure on firm performance: Evidience from Pakistani Firms. International Journal of Academic Research in Economics and Management Sciences, Vol. 3, 2226-3624.

Keshtavar, A., Moeinaddin, M., \& Dehnavi, D. H. (2013). Need for Capital Management and Capital Structure in World Today. International Journal of Modren Sciences, Vol.2, 67-74.

Khrawsih, H. A., \& Khrawish, A. A. (2007). The Determinants of Capital Structure: Evisence from Jordanian Industrial Companies. Vol.24, 173-196. doi:10.4197/Eco.24-1.5

Kipesha, E. F., \& Moshi, J. J. (2014). Capital Structure and Firm Performance; Evidences from Commercial Banks Tanzania. Reseach Journal of Finance and Accounting, Vol.5, No.14.

M.Abbadi, S., \& Abu-Rub, N. (2012). The Effect of Capital Strucure on the Performance of Palestine Financial Institutions. British Journal of Economics, Finance and Management Sciences, Vol.3, 92-101.

Madan, K. (2007). An Analysis of the Debt-Equity Structure of leading hotel chines in India. International Journal of Contemporary Hospitality Management, Vol.19(5), 397-414.

Margaritis, D., \& Psillaki, M. (2007). Capital Strucure and Firm Efficiency. Journal of Business Finane and Accounting, Vol.34, 1447-1469.

Mujahid , M., \& Akhtar, K. (2014). Impact of Capital Structure on Firms Financial performance and Shareholders Wealth: Textile Sector of Pakistan. International Journal of Learning \& Development, Vol.4, 2164-4063.

Mujahid, M. (2014). Impact of Capital Structure on Banking Performance. Research Journal of Finance and Accounting, Vol.5, 2222-2847. 
Naceur, S. B., \& Goaied, M. (2001). The Determinants of the Tunisin Banking Industry Profitability: Panel Evidence. Applied Financial Economics, Vol.11, 317-319.

Nikoo, S. F. (2015). Impact of Capital Structure on Banking Performance: Evidence from Tehran Stock Exchange. International Research Journal of Applied and Basic Sciences, Vol, 9 (7), 1148-1152.

Nirajini, A, \& K B, P. (2013). Impact of Capital Structure on Financial Performance of the Listed Trading Companies in Siri Lanka. International Journal of Scientific and Research Publications, Vol.3(5), 1-9.

Noe, T. H. (1988). Capital Structure and Signaling Game Equilibria. The Review of Financial Studies by Oxford University Press, Vol.1, 331-355.

Rajan, R., \& Zingales, L. (1995). What Do We Know about Capital Structure? Some Evidence from International Data. The Journal of Finance by American Finance Assositaion, Vol. 50,(5), 1421-1461.

Ramadan , I. Z. (2015). An Empirical Investigation of the Trade-off Theory; Evidene from Jordan. International Business Research, Vol.8.

Ebaid, I. E.-S. (2009). The impact of capital-structure choice on firm performance: empirical evidence from Egypt. The Journal of Risk Finance, 10(5), 477 - 487. doi:10.1108/15265940911001385

Mayers, S. (2001). Capital structure. The journal of economics perspective, vol,15(2).

Ross, S. (1997). The Determination of Financial Structure: The Incentive-Signalling Approach. The Bell Journal of Economics, vol,8(1), 23-40. Retrieved from http://www.jstor.org/stable/3003485

Stiglitz, J. (n.d.). On the Irrelevance of Corporate Financial Policy. The American Economic Review, vol, 64(6), 851-866.

Zeitun, R., \& Tian, G. G. (2007). Capital Structure and Corporate Performance:. The Australasian Accounting Business \& Finance Journal, 1(4), 1-40. 